EWELINA SZCZECHOWIAK

ORCID 0000-0003-3414-5550

Uniwersytet im. Adama Mickiewicza

$w$ Poznaniu

\title{
DORADCA ZAWODOWY \\ WE WSPÓŁCZESNYM SYSTEMIE EDUKACYJNYM
}

\begin{abstract}
AвSTRACT. Szczechowiak Ewelina, Doradca zawodowy we wspótczesnym systemie edukacyjnym [Career Advisors in the Contemporary Educational System]. Studia Edukacyjne nr 56, 2020, Poznań 2020, pp. 253-266. Adam Mickiewicz University Press. ISSN 1233-6688. DOI: 10.14746/se.2020.56.14

The position of a career advisor in the contemporary educational system is linked to challenges. The situation on the labor market and its changes over the years are crucial for vocational guidance and lifelong learning. Appropriate support from a specialist, parents of an apprentice and teachers can lead to future educational and professional success. Young people think about self-realization, development, and success; they notice that the course of a career in line with their assumptions depends on getting to know their strengths and weaknesses. The main task of career counselors is to help in choosing the further path of education, which is why their role is so important in the life of young people. The article deals with the reality and ideal model of a career advisor and shows the attitude of young people towards a specialist.
\end{abstract}

Key words: career advisor, role of career counselor, educational and professional career, path of education, vocational guidance

\section{Wprowadzenie}

W latach 70. XX wieku T.W. Nowacki, twórca pedagogiki pracy, sklasyfikował ją jako jedną z subdyscyplin pedagogiki. Zauważył zależność między wychowaniem w szkole a późniejszą pracą w życiu każdej jednostki. Nauczanie człowieka w myśl edukacji ustawicznej dąży do podnoszenia kwalifikacji zawodowych. Ich początki sięgają szkolnej edukacji oraz rad specjalisty z dziedziny poradnictwa i doradztwa zawodowego ${ }^{1}$. Wzajemne zależności między rynkiem edukacyjnym a rynkiem pracy skonstatował

\footnotetext{
${ }^{1}$ J. Wierzejska, Nowe obszary i problemy badawcze pedagogiki pracy, Lublin 2017, s. 43.
} 
K. Denek². Autor spostrzegł, że występuje między nimi pewna współzależność jeśli chodzi o zdobycie wykształcenia, kwalifikacji i kompetencji, które zagwarantują bezpieczeństwo późniejszego zatrudnienia ${ }^{3}$. Dlatego, wczesny rozwój zawodowy człowieka ma kluczowe znaczenie szczególnie w realiach gospodarki opartej na wiedzy. Stąd dydaktyka pracy porusza między innymi problematykę związaną z kwestią zależności nauczania i uczenia się od treści nabytych w początkowych szczeblach oświatowej drabiny. Dzięki wczesnemu procesowi jednostka może się rozwijać, kształtować swoje umiejętności, zdolności, poznawać zainteresowania, predyspozycje, modelować postawy, które są kluczowymi wymaganiami w późniejszej pracy4.

Współczesny rynek zatrudnienia stawia przed ludźmi coraz wyższe wymagania wobec ich kwalifikacji zawodowych. Nieuniknione staje się uzupełnienie wykształcenia, a nawet przebranżowienie. Postępująca digitalizacja przekształca charakter pracy. Wobec tego, każdy pracownik jest zmuszony do dostosowania się do nowych warunków, metod i treści pracy. Wyłania się potrzeba permanentnej edukacji wywodzącej się od procesu nauczania poprzez uczenie się pod kierunkiem profesjonalisty, do zainspirowania samokształcenia przez kompetentnego specjalistę. Konsekwencją tak realizowanej edukacji jest wychowanie człowieka chcącego kształcić się z własnej inicjatywy. Zapewnia ten sposób postępowania nasza oświata i państwa Unii Europejskiej, które wspierają rozwój kształcenia ustawicznego i kreowanie społeczeństwa opartego na wiedzy ${ }^{5}$.

Zewnętrzne warunki i współczesny polski rynek pracy przejmuje nowe trendy i tendencje wzorując się na zachodnich. Powstaje coraz więcej etatów, w szczególności specjalistów z branży IT 6 . Konsekwencją wskazanej opcji jest to, że pracodawcy z różnych dziedzin zaczynają borykać się z brakiem odpowiednio wykwalifikowanych pracowników w innych dziedzinach. W tej sytuacji absolwenci zasadniczej szkoły zawodowej cieszą się największym powodzeniem na rynku pracy. Za nimi klasyfikują się osoby z wykształceniem wyższym, a następnie osoby legitymujące się wykształceniem średnim zawodowym ${ }^{7}$. A. Bańka zauważa, że równowaga na rynku pracy jest zdarzeniem incydentalnym. Przyczyną tego zjawiska jest brak ustabilizowania w strukturze zawodów, które nie są adekwatne do aktualnych potrzeb gospodarki i globalizacji. Dlatego, w pewnych zawodach mówimy o nadmiarze lub deficycie kandydatów do pracy. Zwracamy uwagę na brak wykwalifikowanych

\footnotetext{
${ }^{2}$ K. Denek, Wartości edukacji zawodowej, Pedagogika Pracy, 1994, 23, s. 34.

${ }^{3}$ J. Szłapińska, Podnoszenie wartości kapitału edukacyjnego pracowników w systemie ksztatcenia ustawicznego, Poznań 2009, s. 22.

4 T.W. Nowacki, U. Jeruszka, Podstawy dydaktyki pracy, Warszawa 2004, s. 41.

5 Tamże, s. 45.

${ }^{6}$ Absolwent na rynku pracy - poradnik dla Ucznia i Nauczyciela, Warszawa 2011, s. 28-29.

7 Tamże.
} 
pracowników legitymujących się odpowiednimi kompetencjami i kwalifikacjami wymaganymi do podjęcia danego zatrudnienia ${ }^{8}$. Jedyną możliwością zmiany jest pokładanie nadziei $\mathrm{w}$ młodych ludziach będących $\mathrm{w}$ tym momencie na początku swojej edukacyjnej kariery. Udzielając im pomocy poprzez doradcę zawodowego, posiadającego wiedzę z dziedziny psychologii, pedagogiki i socjologii, sprawimy, że na rynek pracy wejdą silne osobowości, potrafiące podejmować trafne decyzje edukacyjno-zawodowe. Znające realia panujące na współczesnym rynku pracy oraz potrafiące dostosowywać się do zaistniałych zmian. Posiadające wysoko rozwinięte kompetencje zawodowe oraz społeczne, tak ogromnie pożądane przez pracodawców niemal na każdym stanowisku pracy ${ }^{9}$.

\section{Edukacyjne inspiracje i działalność doradcy zawodowego w szkole}

Doradca zawodowy to osoba udzielająca pomocy, w formie indywidualnych i grupowych porad zawodowych, dorosłym i młodzieży. Pomoc ta dotyczy wyboru zawodu i kierunku kształcenia. Uwzględnia on możliwości psychofizyczne i sytuację życiową klientów, a także potrzeby rynku pracy oraz możliwości systemu edukacyjnego. Współpracuje z rodzicami i nauczycielami w procesie orientacji zawodowej uczniów. Wykorzystuje w tym celu wiedzę o zawodach, znajomość psychologicznych i pedagogicznych technik, diagnozę rynku pracy oraz techniczne środki przekazywania informacji zawodowej. Doradca zawodowy pełni kluczową rolę w planowaniu kariery edukacyjno-zawodowej młodzieży. Warto jednak zadbać, aby realizacją zajęć z zakresu doradztwa zajęły się osoby kompetentne, o odpowiedniej wiedzy i umiejętnościach społecznych, pozwalające młodemu człowiekowi otworzyć się na tyle, aby została mu udzielona specjalistyczna pomoc ${ }^{10}$.

Stanowisko doradcy zawodowego w polskiej oświacie jest niedoceniane. Funkcję tę bardzo często pełni pedagog szkolny lub psycholog bez odpowiedniego przygotowania merytorycznego. Zostaje wyznaczony do pełnienia tego stanowiska przez dyrektora placówki. Najczęściej kończy studia podyplomowe tylko po to, aby szkolnictwo w ramach oszczędności mogło urzeczywistnić wewnątrzszkolny system doradztwa zawodowego, zatrudniając jedną osobę na dwa stanowiska. Jednak rząd nie uzmysławia sobie, jak osobne stanowisko doradcy zawodowego może pozytywnie wpłynąć na

${ }^{8}$ A. Bańka, Zawodoznawstwo, doradztwo zawodowe, pośrednictwo pracy: psychologiczne metody i strategie pomocy bezrobotnym, Poznań 1995, s. 17.

9 Absolwent na rynku pracy - poradnik dla Ucznia i Nauczyciela, s. 28-29.

10 A. Łukasiewicz, G. Sołtysińska, Szkolny doradca zawodowy, Warszawa 2003, s. 26. 
młodzież i ich trafne decyzje edukacyjno-zawodowe. Byłoby to także korzystne dla polskiego rynku pracy. Pewnym fenomenem jest położenie nacisku na przedmioty ścisłe $\mathrm{w}$ placówkach, na odpowiedni poziom przyswojenia wiedzy przez młode osoby w licznych testach. Uczniowie osiągający tam najlepsze stopnie, mają rozwinięte umiejętności dobrej organizacji pracy. Są to często osoby systematyczne i ambitne. Nie oznacza to, że ich wybór szkoły czy zawodu jest dla nich łatwiejszy. Wszystko zależy od uświadomienia i odkrycia w małoletnich pasji, rozwijania talentów oraz zainteresowań. Nikt tak nie rozbudzi myślenia o przyszłości, pracy, przedsiębiorczości, edukacji w młodym człowieku jak doradca zawodowy ${ }^{11}$.

Niewątpliwie praca jest jedną z najważniejszych wartości w życiu człowieka. Stawiamy ją zaraz obok rodziny, religii i przyjaciół. Wiąże się ze zdobywaniem dóbr materialnych. Jednakże, bardzo istotne jest, aby w parze z korzyściami finansowymi postępował rozwój preferencji, zamiłowań oraz dążeń do samorealizacji, co doprowadzi do osiągnięcia satysfakcji na stopie prywatnej i zawodowej ${ }^{12}$. Niezwykle trafnie opisuje to piramida A. Maslowa z punktu widzenia pracownika. Poprzez jej pryzmat można zauważyć, że w ubiegłym wieku praca opierała się głównie na zaspokojeniu potrzeb niższego rzędu, opartych na wykonywaniu jej w godziwych warunkach, otrzymaniu wynagrodzenia (potrzeby fizjologiczne) oraz stabilizacji. Wszystko po to, aby zapewnić sobie i swoim bliskim dogodne warunki życia. Współcześnie możemy zaobserwować tendencję dążenia do zaspokojenia potrzeb wyższego rzędu. Potrzeby społeczne opierają się na wykonywaniu pracy w zgranym, lubianym zespole pracowniczym, integracji z miejscem pracy, poczuciu przynależności do wybranej elity. Kolejno możemy wyróżnić potrzebę uznania, opierającą się na nawiązaniu relacji z osobami z branży, poczuciem sukcesu, prestiżu. Tutaj uwidaczniają się pierwsze materialne oznaki awansu w organizacji, w postaci samochodu, laptopa, czy komórki służbowej. Jednak najważniejsze jest to, iż praca wiąże się z własnym rozwojem. Samorealizacja wysuwa się na pierwszy plan w drodze do szczęścia człowieka. Z kolei, w organizacji można zaobserwować ją poprzez wprowadzanie własnych pomysłów, angażowanie się w różne projekty, poszerzanie swojej wiedzy poprzez kształcenie całożyciowe. W dążeniu do samorozwoju jednostka powinna skupić się na swoich potrzebach, rozwijaniu własnych pasji i zamierzeń, ponieważ dopiero wówczas będzie mogła osiągnąć spełnienie na stopie zawodowej i prywatnej ${ }^{13}$.

${ }^{11}$ Projekty ORE realizowane w latach 2016-2018 w ramach PO WER dotyczące kształcenia zawodowego, Doradztwo zawodowe -perspektywy i praktyczne rozwiazania, Wrocław 2017r., dostępny w Internecie: http://dodn.dolnyslask.pl/images/p.\%20B.\%20Mayer-Gawron.pdf [dostęp: 02.01.2018],

${ }_{12}$ K. Belczyk, Sedlak \& Sedlak, Praca - wartość $i$ znaczenie na przestrzeni lat, w: http:/ / www. rynekpracy.pl/artykul.php/typ.1/kategoria_glowna.322/wpis.184. [dostęp: 05 styczeń 2016].

${ }_{13}$ R.W. Griffin, Podstawy zarzadzania organizacjami, Warszawa 2007, s. 522. 
Łatwo zauważyć, że największe znaczenie dla nas ma rozwijanie potrzeb wyższego rzędu, oczywiście w momencie, kiedy potrzeby niższego rzędu są zaspokojone. Współczesne pokolenie dąży do rozwoju osobistego, nie godząc się na spokojną, monotonną egzystencję pozwalającą zapewnić podstawowe potrzeby. Wymaga to znacznie większego nakładu pracy niż było to wcześniej. Realizacja tych celów wymaga od osoby odnalezienia własnej drogi czy ścieżki zawodowej kariery. Tutaj rola doradcy zawodowego ma kluczowe znaczenie, szczególnie na szczeblach wczesnej edukacji. Młodzi ludzie nie znający siebie, własnych możliwości będą mieli poczucie niespełnienia. Wówczas ich egzystencja skończy się na zaspokajaniu potrzeb niższego rzędu. Może do skutkować frustracją, złym samopoczuciem, a nawet depresją. Ciągłe poczucie niższości, lęki w podjęciu zatrudnienia czy dalszego rozwoju sprawi, że te osoby nie odczują potrzeby uznania i samorealizacji, które zdecydowanie ukierunkowują nasze życie i nadają mu większej wartości i poczucia życiowego spełnienia.

Zapotrzebowanie na doradców zawodowych na rynku pracy jest bardzo duże. Państwo stawia jednak ogromne wymagania przed poradnictwem zawodowym. Oczekuje od niego odpowiedzialności za sytuacje dotyczące rynku pracy, poprawy wyników i wydajności oraz wspierania celów rozwoju ekonomicznego. Do politycznych celów poradnictwa należy przekonanie jak największej liczby dorosłych osób do dokształcania się i nabywania dodatkowych kwalifikacji. Edukacja dorosłych znacznie polepszy lub wzmocni ich sytuację na rynku pracy. Również oferowane liczne szkolenia zwiększą zakres kompetencji zawodowych oraz społecznych. Poszerzą lub usystematyzują ich wiedzę. W tej sytuacji doradca zawodowy powinien przygotować młodzież, jak i osoby dorosłe do adaptacji do nowych warunków pracy i mobilności zawodowej. Jego działania powinny skutkować zmniejszeniem stopy bezrobocia oraz efektów destabilizacji rynku pracy. Udzielaniu wsparcia i pomocy jednostkom nieprzystosowanym do zmian oraz obawiających się przyszłości. Doradca, dzięki swojej eksperckiej wiedzy dotyczącej sytuacji na rynku pracy, może ją wykorzystać przy zmniejszaniu liczby osób uzależnionych od świadczeń społecznych.

Natomiast, poradnictwo zajmuje się również osobami starszymi, przede wszystkim zmniejszając dyskomfort przechodzenia osób w wieku mobilnym na wcześniejszą emeryturę. Wspiera pojęcie kształcenia ustawicznego i co najważniejsze - przyczynia się do odczucia satysfakcji z wykonywanej pracy przez obywateli ${ }^{14}$. Państwa europejskie przechodzą bardzo szybkie zmiany w swojej gospodarce, dlatego niezwykle istotną rolę odgrywa poradnictwo.

${ }^{14}$ R. Sultana, Strategie ustug poradnictwa zawodowego w społeczeństwie wiedzy - europejskie trendy, działania i wyzwania, Luksemburg 2004, s. 50-63. 
Dzięki niemu mogą być promowane nowe metody szkolenia i przeszkalania zarówno dla młodych, jak i starszych pracowników. Jednak, poradnictwu zawodowemu stawia się wiele wyzwań. Niektóre z nich są bardzo trudne do realizacji, gdyż muszą upłynąć lata, aby były widoczne.

Dobry przykład stanowi opisanie tradycyjnego sposobu świadczenia usług poradnictwa przez szkołę. Jest to miejsce, w którym młodzi ludzie mogą zetknąć się z poradnictwem edukacyjnym i zawodowym. Tradycyjne usługi poradnictwa przez dłuższy czas były skoncentrowane na gimnazjach. Otwierały one przed nimi określone drogi edukacyjne, które wiązały się z wykonywaniem pracy przez określone grupy pracowników. W tym systemie brakowało przenikalności między ścieżkami, wskutek czego podejmowane decyzje przez młodego człowieka były nieodwracalne i ryzykowne. Pomoc doradcza opierała się na odbywaniu indywidualnych rozmów z uczniami $\mathrm{w}$ momencie podejmowania kluczowego rozstrzygnięcia wyboru drogi zawodowej, co łączyło się z zaniedbaniem zachowania poradnictwa w szkołach podstawowych. $\mathrm{W}$ momencie, kiedy dalsza edukacja nie była dostępna dla przeciętnego człowieka, poradnictwo niemalże nie istniało. W związku z tym większość państw porzuciła tradycyjny model świadczenia usług doradczych i porozmieszczała je na różnych szczeblach szkolnej drabiny. Dzięki temu poradnictwo zawodowe poszerzyło się i świadczyło znacznie bogatsze usługi. Obecnie możemy zaobserwować, że młodzież ma łatwiejszy i znacznie bogatszy dostęp do świadczenia dalszej nauki ${ }^{15}$.

Proponowane oferty wielu szkół, kursów, czy szkoleń coraz częściej umożliwiają edukację w pełnym wymiarze czasu lub tylko w częściowym, kształcenie blisko miejsca zamieszkania lub na odległość. Coraz częściej oferty edukacyjne dostosowywane są do życia człowieka. Osoby pracujące, wychowujące dzieci, czy osoby starsze mogą się dokształcać dzięki ofercie przystosowanej do ich indywidualnych potrzeb. Dzięki temu dostęp do edukacji stał się bardziej otwarty i demokratyczny. Bardzo ważne jest, aby osoby młode jak i starsze miały dostęp do poradnictwa, co ułatwi im podejmowanie korzystnych wyborów odnośnie ścieżki kształcenia. Wobec tego, doradca zawodowy w placówce oświatowej ma wiele do zaoferowania. W szczególności może pomóc przezwyciężyć kłopoty w nauce i kształtować umiejętność uczenia się wśród uczniów. Mimo zmian nadal zauważa się brak specjalistycznej pomocy uczniom. Ponadto, brak obecności formalnie utworzonych służb poradnictwa, szczególnie w szkołach podstawowych, skutkuje niemożnością formowania u małoletnich trwałych nawyków kształcenia się i umiejętności kierowania swoimi postępami w nauce oraz całożyciowej pracy, lecz raczej ujawnienia się podejścia z natury psychologicznego, profilaktycznego i tera-

${ }^{15}$ Tamże. 
peutycznego do ucznia. Takie stanowisko nie jest związane z celem poradnictwa. Stanowi je zachęcenie i wskazanie korzyści z nauki, jakiego doświadcza się przez całe życie. Łączy się to z pracą nad swoją edukacyjną karierą i rozwijaniem stosownych zawodowych predyspozycji. W Holandii niektóre placówki oświatowe wprowadziły system teczek zorientowanych na poradnictwo. Natomiast w Belgii nastąpiło odejście od dominującego psychologicznego podejścia do opieki nad wychowankiem. Zwrócono uwagę na pochodzenie społeczne, ekonomiczne i kulturalne w tworzeniu indywidualnej kariery edukacyjnej ucznia ${ }^{16}$.

\section{Inspiracje badawcze}

19 maja 2016 roku przeprowadziłam badania na grupie 39 uczniów ówczesnego Gimnazjum im. Noblistów w Rokietnicy, miejscowości położonej w gminie wiejskiej, w powiecie poznańskim. Materiał uzyskany dzięki badaniu został poddany weryfikacji oraz dokładnej analizie. Wszystko to przyczyniło się do opracowania wyników badań własnych, zamieszczonych poniżej. Uzyskane rezultaty były efektem sprecyzowania trzech celów: poznawczego (który wiązał się z ukazaniem roli doradcy zawodowego w kształtowaniu kariery edukacyjno-zawodowej młodzieży), praktycznego (obejmującego ustalenie wskazówek pedagogicznych dla doradcy zawodowego pomagającego młodzieży gimnazjalnej w kształtowaniu ich kariery edukacyjno-zawodowej) oraz teoretycznego (łączącego się z opracowaniem idealnego modelu osoby doradcy zawodowego). Problemem głównym było pytanie: jaka jest rola doradcy zawodowego w kształtowaniu kariery edukacyjno-zawodowej młodzieży w wieku gimnazjalnym? Wykorzystano metodę sondażu diagnostycznego. Techniką była ankieta audytoryjna, natomiast narzędziem kwestionariusz ankiety, który zawierał 19 pytań dotyczących pojęcia kariery, źródeł pozyskiwania informacji o dalszej ścieżce kształcenia, stopnia trudności, kryteriów wyboru szkoły ponadgimnazjalnej, oceny zajęć z doradztwa zawodowego realizowanych w placówce oraz samego doradcy.

Pojęcie kariery według respondentów jest utożsamiane z pieniędzmi oraz z osiągnięciem sukcesu. Młodzi ludzie karierę identyfikują z rozwojem oraz poczuciem samorealizacji, która stanowi najważniejszą składową w piramidzie A. Maslowa. Również wysoko oceniane jest podejmowanie decyzji oraz realizowanie własnych marzeń. Współczesna młodzież coraz częściej bierze pod uwagę czynniki pozamaterialne w osiąganiu kariery.

16 Tamże. 
Źródłem pozyskiwania informacji przez młodzież, związanych z wyborem szkoły ponadgimnazjalnej, są drzwi otwarte szkół oraz Targi Edukacyjne odbywające się na terenie Międzynarodowych Targów Poznańskich, na trzecim miejscu klasyfikują się dopiero strony internetowe, a na czwartym szkoła. W dobie tak rozwiniętej technologii bardzo dobrą wiadomością jest to, że młodzi ludzie postanawiają szukać informacji osobiście. Odwiedzają placówki znajdujące się w kręgu ich zainteresowań oraz idą na Targi Edukacyjne, na których mogą spotkać nauczycieli, jak również uczniów będących obecnie abiturientami danej szkoły, którzy z pewnością powiedzą im więcej niż strony internetowe. Na ostatnim miejscu znalazła się szkoła. Tak niska gratyfikacja szkoły może wynikać z braku udostępnienia respondentom odpowiedniej ilości informacji. Posługując się dodatkowymi pytaniami, dowiedziałam się, iż gimnazjaliści w ogóle nie korzystają z informacji pochodzących z Centrum Doradztwa Zawodowego oraz Krajowego Ośrodka Wspierania Edukacji Zawodowej i Ustawicznej. To szokująca wiadomość, ponieważ szkolny doradca zawodowy jest wyposażany $\mathrm{w}$ materiały pochodzące $\mathrm{z}$ tych organizacji. Ponadto, badani w jednym z pytań wskazali, że prezentowane przez pedagoga szkolnego projekcje filmowe dotyczące zawodów są przestarzałe i nudne. Może to świadczyć, że doradca nie wie o projekcjach, albo świadomie nie korzysta na przykład z filmów animowanych zatytułowanych „Rozwijam skrzydła", które zostały stworzone po to, aby w prosty i przystępny sposób pomóc młodzieży gimnazjalnej dokonać odpowiedniego wyboru zawodu i szkoły.

Młodzi ludzie przy wyborze szkoły ponadgimnazjalnej kierują się raczej opinią rodziców oraz znajomych. Niestety, na ostatnim miejscu znajduje się opinia takich specjalistów, jak psycholog, pedagog i doradca zawodowy. Często rodzice kierują się własnym doświadczeniem, a niestety obecny rynek pracy i program szkolny uległ drastycznej zmianie, co może świadczyć, że opiekunowie mogą mieć przestarzałą wiedzę. Również bardzo ważne jest to, aby doradca przeorientował stereotypowe myślenie rodziców i ich subiektywne podejmowanie decyzji na uwzględniające zainteresowania, czy predyspozycje oraz opinie ucznia. Jest to niezwykle trudne zadanie, dlatego doradca zawodowy powinien mieć wiedzę z dziedziny psychologii i socjologii tak, aby pomóc rodzicom uczniów wesprzeć ich, szczególnie w procesie przeprowadzania rozmów z podopiecznymi.

Respondenci $\mathrm{w}$ większości wypowiedzieli się, że chętnie uczestniczą $\mathrm{w}$ zajęciach $\mathrm{z}$ doradztwa zawodowego. Poproszeni o uzasadnienie swoich opinii (nie wszyscy to uczynili) uargumentowali następująco: najwięcej przesłanek otrzymałam w grupie, która uważała, że niechętnie uczestniczy w zajęciach z doradztwa zawodowego. Wskazali oni na niekompetencje osoby prowadzącej te zajęcia, brak życzliwości z jej strony, nerwowość oraz posłu- 
giwanie się krzykiem wobec ucznia. W większości ocenili zajęcia jako nudne, schematyczne, nieprzydatne, zbędne, a doradcę jako osobę mało pomocną, bezpośrednio wpływającą na decyzje uczniów. Wskazali również na brak realizacji tematów odnoszących się do poznania siebie. Niektórzy uczniowie stwierdzili, że nie widzą możliwości kontynuowania tych zajęć i że podczas nich nie są podejmowane tematy, które mogłyby pozwolić młodzieży poznać ich słabe i mocne strony. Respondenci, którym trudno było odpowiedzieć na to pytanie wyszczególnili, że wynika to z małej liczby takich zajęć, ciągłym realizowaniu przez doradcę ankiet i testów, które nie są podsumowywane w odpowiedni sposób, co sprawia, że uczniowie nie widzą sensu ich wypełniania, przez co ocenili oni zajęcia jako mało interesujące.

Z kolei, ankietowani wypowiadający się pozytywnie na temat chęci uczestnictwa $\mathrm{w}$ zajęciach, określili je jako ciekawe, poszerzające wiedzę z zakresu rozpoznania zawodów. Mogą oni zdobyć informacje odnośnie szkół, profili, zawodów. Zajęcia te pomagają im w podjęciu decyzji związanej w wyborem szkoły. Badani zwrócili uwagę, że mogą pogłębić wiedzę, wysłuchać osoby doświadczonej, poznać siebie, a zdobyte informacje będą dla nich użyteczne. $\mathrm{W}$ tej grupie pojawiły się odpowiedzi, iż zajęcia te realizowane są zamiast innych przedmiotów. Mimo że większość chętnie uczestniczy w zajęciach $\mathrm{z}$ doradztwa zawodowego przeprowadzanych w szkole, to zdecydowanie w opiniach ankietowanych wybrzmiewa większa niechęć do prowadzącego niż do samej tematyki zajęć.

Większość respondentów opowiedziała się za realizacją zajęć z doradztwa zawodowego w szkole przez osobę zatrudnioną wyłącznie na stanowisku doradcy zawodowego, a nie jak obecnie czyni to pedagog szkolny, sprawując funkcję doradczą. Może to świadczyć, iż pedagog szkolny nie jest osobą adekwatną na tym stanowisku. Większość respondentów nie zwróciła się po pomoc w wyborze dalszej ścieżki kształcenia do pedagoga szkolnego ze swojej szkoły. Może to wynikać z relacji uczniów z nauczycielem i ich niechęci do jakiejkolwiek pomocy ze strony tego specjalisty. Natomiast, sam stosunek do zajęć z doradztwa zawodowego był wśród respondentów pozytywny. Spośród 15 kafeterii, badani mogli maksymalnie wybrać 3 odpowiedzi dotyczące sytuacji, w których zwróciliby się po pomoc do doradcy zawodowego. Na pierwszym miejscu znalazł się wybór szkoły ponadgimnazjalnej. Na drugim - wybór odpowiedniego zawodu, a na trzecim - brak planów na przyszłość. Równie wysoko badani ocenili pomoc w poznaniu swoich możliwości oraz brak wiedzy o rynku pracy. Pozostałe kafeterie były dla nich mniej istotne $\mathrm{w}$ porównaniu z resztą. Z uzyskanych odpowiedzi można było wywnioskować, że 24 badanych wybiera się do technikum, 10 ankietowanych decyduje się na liceum ogólnokształcące, a jedynie 5 osób chce się udać do zasadniczej szkoły zawodowej. Zdecydowana większość respondentów opowiada się 
za technikum. Stanowi to pewne zaskoczenie, jako że jeszcze kilka lat temu wyborem większości gimnazjalistów było liceum ogólnokształcące, a najniżej klasyfikowała się zasadnicza szkoła zawodowa, co niestety tak pozostało. Podsumowując odpowiedzi ankietowanych, dostrzegalne jest pragnienie uzyskania pomocy od doradcy zawodowego w sytuacjach odpowiedzialnych za ich karierę edukacyjno-zawodową. Jednakże, niezwykle istotne dla nich jest, aby stanowisko to zajmowała osoba będąca wyłącznie doradcą zawodowym, a nie również pedagogiem szkolnym. Uczniowie realizujący program nauczania III klasy gimnazjum najbardziej potrzebują pomocy w zakresie wyboru dalszej ścieżki kształcenia ${ }^{17}$ i samopoznania różnych zawodów.

Niestety, po przeprowadzeniu badań i wyznaczeniu celów można było dobitnie zauważyć, że stosunek gimnazjalistów do doradcy zawodowego jest negatywny. Może to wynikać z małej liczby godzin z doradztwa zawodowego lub z ich złego zorganizowania, ponieważ niektórym uczniom wystarczy kilka lekcji grupowych, które pozwolą im jedynie utwierdzić się, jakimi są osobami oraz jaki profil kształcenia będzie dla nich odpowiedni i jaką szkołę wybiorą. Nie dla każdego ucznia jest to oczywiste. Niektórzy potrzebują dużo więcej czasu oraz częstszych indywidualnych spotkań ze specjalistami.

Połączenie stanowiska pedagoga szkolnego z doradcą zawodowym nie stanowi dobrego rozwiązania, ponieważ gimnazjaliści doznający pewnych nieprzyjemności z panią pedagog w szkole, nie zwrócą się do niej po pomoc przy wyborze szkoły ponadgimnazjalnej. Należy podkreślić, że okres dojrzewania jest niezwykle burzliwy i trudny dla młodego człowieka. Boryka się on wówczas z wieloma przeciwnościami losu, poczuciem niesprawiedliwości, brakiem zrozumienia oraz wieloma jeszcze innymi problemami. Szuka więc osoby, do której mógłby zwrócić się po pomoc, zwierzyć ze swoich problemów, wyznając pewne tajemnice psychologowi lub pedagogowi w szkole. Nie ma on pewności, że to co powiedział „zostanie w gabinecie”, a bardzo często są wyciągane konsekwencje, czy zostają prowadzone rozmowy z rodzicami. Być może, idealnym rozwiązaniem dla gimnazjalistów byłaby obecność doradcy zawodowego w szkole, nie będącego jednak pracownikiem szkolnym, lecz pracującym jako osoba z zewnątrz i wówczas stosunek młodzieży do specjalisty mógłby być całkiem inny.

Dla gimnazjalistów nadal najważniejsza jest opinia ich rodziców. Zatem, wynik przeprowadzonych badań nie szokuje. Najistotniejsze jest jednak to, aby rodzice uczniów byli wyposażeni w niezbędne wiadomości. Mogą je uzyskać od specjalisty, który na zebraniach wyposażyłby opiekunów uczniów w odpowiednią wiedzę oraz pokazał, gdzie można szukać informacji bądź zgłosić się po pomoc. Wychodząc naprzeciw oczekiwaniom, doradca zawo-

${ }_{17}$ Patrz: A. Cybal-Michalska, Młodzież akademicka a kariera zawodowa, Kraków 2013. 
dowy mógłby zorganizować spotkania szkoleniowo-informacyjne dla rodziców. Pytać ich o zdanie i realizować spotkania lub szkolenia wedle ich sugestii. Ponadto, aby stworzyć dobre relacje z rodzicami, doradca powinien wyzbyć się postawy „nauczycielskiej”. Rodzice poprzez zabiegi couchingowe poczuliby się bardziej zmotywowani do wprowadzania pewnych modyfikacji w swoim życiu, co rzutowałoby na zmianę postaw ich dzieci. Zaangażowanie i włączenie rodziców w wybór ścieżki zawodowej, rozpoznania zawodowego jest niezwykle ważne. Można tego dokonać za pomocą; 1) job shadowing, który polega na pobraniu nauki praktycznej poprzez „chodzenie za pracownikiem jak cień". Uczeń wybierając zawód może udać się do miejsca pracy, w którym w przyszłości chciałby pracować i towarzyszyć pracownikowi ${ }^{18}$, 2) zaproszenia rodziców, którzy opowiedzą o swoich zawodach i ścieżce edukacyjno-zawodowej, jaką musieli przejść, 3) zorganizowania spotkań dla rodzin szkolnych ze znanymi, inspirującymi ludźmi, którzy mogą zaciekawiuć ich pociechy, jak też ich samych.

Zajęcia z doradztwa zawodowego dotyczące podjęcia decyzji edukacyjno-zawodowej nie powinny być wyłącznie realizowane w klasach trzecich, gdzie gimnazjaliści muszą już dokonać odpowiedniego wyboru szkoły ponadgimnazjalnej. Powinni to robić znacznie wcześniej. Zatem, zmiana organizacji z modelu linearnego kształcenia na model modułowy pozwoliłaby młodzieży poznać siebie, swoje mocne i słabe strony, zdobyć wystarczającą wiedzę z zakresu rynku pracy, zawodów oraz podjąć trafną, przemyślaną decyzję odnośnie wyboru dalszego kształcenia w ciągu kolejnych lat nauki. Zainteresowania, aspirację oraz uzdolnienia na przestrzeni lat mogą ulec przeobrażeniu. Uczeń może odkryć w sobie nowe pasje, hobby, które będzie chciał wykorzystać przy wyborze odpowiedniej szkoły. Program skierowany na realizację lekcji z zakresu samopoznania wyłącznie w pierwszej klasie jest niewystarczający. Dlatego, wprowadzenie modelu modułowego sprawi, że te same obszary związane z poznaniem siebie, wiedzą odnośnie rynku pracy oraz wyborem dalszej edukacji będą pogłębiane, rozszerzane i uzupełniane ${ }^{19}$.

Korzystnie urzeczywistniane kształcenie, zaangażowanie i poczucie spełnienia może sprawić doradca i jego kompetencje zawodowe, które będą pełnić kluczową rolę nie tylko w planowaniu kariery edukacyjno-zawodowej młodzieży, ale również w osiągnięciu samorealizacji przez ludzi. Być może w przyszłości będziemy mieli do czynienia z osobami mniej sfrustrowanymi, realizującymi się w swoim życiu, nie popadającymi w depresję, czy różne choroby wynikające ze stresujących warunków w miejscu pracy. Należy pa-

${ }_{18}$ Job shadowing w: Stownik HR, http://www.jobfitter.pl/slownik-hr/job-shadowing [dostęp: 2 marzec 2016].

${ }_{19}$ M. Rosalska, Warsztat diagnostyczny doradcy zawodowego, Warszawa 2012, s. 27. 
miętać, że kiedy wykonujemy coś, co nie sprawia nam radości, wówczas odbieramy sobie cząstkę siebie.

Wprowadzenie obowiązku realizacji doradztwa zawodowego w szkołach podstawowych w obecnych klasach VII i VIII jest początkiem wprowadzenia pozytywnych zmian w szkolnictwie. Osobne zajęcia z doradztwa będą szansą dla uczniów do rozwinięcia swoich pasji, zainteresowań, poznania predyspozycji, swoich mocnych i słabych stron. Dzięki wyznaczonym tygodniowym godzinom specjaliści mogą swobodniej prowadzić zajęcia związane z wyborem szkoły ponadpodstawowej, aby pomóc młodzieży w podjęciu decyzji edukacyjno-zawodowej. Również znacznie ciekawsza oferta szkół branżowych, które weszły na miejsce zasadniczych szkół zawodowych może sprawić, że coraz więcej młodych osób będzie interesować się podjęciem nauki w tych placówkach. Czas pokaże, czy w tych szkołach pojawi się doradca zawodowy, który nie będzie miał ograniczonego kontaktu z uczniami oraz zbyt małej liczby godzin. Nasuwa się natomiast inne pytanie: czy doradca, a w szczególności osoba odpowiedzialna za doradztwo zawodowe w szkole, wyznaczona przed dyrektora, wie, jak sensownie wykorzystać te godziny zajęć? ${ }^{20}$

\section{Podsumowanie}

Niniejszy artykuł pozwolił na urzeczywistnienie celu poznawczego, który wiązał się z ukazaniem roli doradcy zawodowego w kształtowaniu ścieżki kariery młodych ludzi ${ }^{21}$. Wyniki badań jednoznacznie pokazują, że stosunek młodzieży do specjalisty $\mathrm{w}$ ich szkole uległ zmianie, ze względu na prowadzenie zajęć przez pedagoga szkolnego. Niestety, jest to jedyna osoba odpowiedzialna za realizację Wewnątrzszkolnego Systemu Doradztwa Zawodowego w placówce. Najprawdopodobniej nie ulegnie to zmianie ze względu na oszczędności w budżecie państwa. Z kolei, sformułowanie celu teoretycznego pozwoliło na opracowanie idealnego modelu doradcy zawodowego. Jego zadaniem jako specjalisty jest nawiązanie ścisłej współpracy z rodzicami i nauczycielami, udzielanie porad, wskazówek, informacji oraz sugerowanie (nie narzucanie) pewnych rozwiązań zaistniałych problemów. Uświadamianie istotności roli doradztwa zawodowego w życiu młodego człowieka będzie polegać na osiągnięciu przez niego autorefleksji, samoświa-

${ }^{20}$ Projekty ORE realizowane $\mathrm{w}$ latach 2016-2018 w ramach PO WER dotyczące kształcenia zawodowego, Doradztwo zawodowe -perspektywy i praktyczne rozwiazania, Wrocław 2017, http:// dodn.dolnyslask.pl/images/p.\%20B.\%20Mayer-Gawron.pdf.[dostęp: 01.02.2018].

${ }^{21}$ A. Cybal-Micjalska, Dylematy tożsamościowe młodzieży w sytuacji zmiany kulturowej, [w:] Młodzież wobec niegościnnej przyszłości, red. R. Leppert, Z. Melosik, B. Wojtasik, Wrocław 2005, s. 113-121. 
domości i samorealizacji w odniesieniu do pracy i miejsca jej wykonywania. Łączy się to z wyborem odpowiedniej drogi kariery edukacyjnej i zawodowej oraz dostosowania się do obecnie pojawiających się zmian ekonomicznych $^{22}$. Dlatego, doradca zawodowy, zdaniem B. Wojtasik, nie może opierać się na przyjmowaniu dyrektywnej postawy, a wręcz przeciwnie - powinien być to spolegliwy opiekun, konsultant, leseferysta. Wówczas jego rola powinna polegać na wspieraniu ucznia w wyborze dalszej ścieżki edukacyjno-zawodowej. Specjalista ten ma lepiej zrozumieć swojego rozmówcę, a on przy odpowiednim wsparciu powinien sam kształtować swoją tożsamość23. Preferowanym idealnym modelem doradcy zawodowego staje się doradca - partner ucznia, pomagający mu skonstruować indywidualny szlak kariery, przy czym nie ukierunkowuje go tylko na jedną konkretną profesję. Odznacza się takimi cechami, jak otwartość, życzliwość, szacunek wobec rozmówcy. Poświęca młodemu człowiekowi wiele czasu, uwagi, pobudza go do działania, autoanalizy, odkrywania swoich mocnych i słabych stron. Doradca nie udziela rad, ani nie podejmuje decyzji; wszelkie działania realizowane są przez klienta w zgodzie z samym sobą, co za tym idzie - doradca nie ponosi żadnej odpowiedzialności ${ }^{24}$. Staje się właściwym mentorem pokazującym odcienie rozmaitych zawodów, które są bardziej lub mniej aprobowane i doceniane w zewnętrznym otoczeniu.

\section{BIBLIOGRAFIA}

Absolwent na rynku pracy - poradnik dla ucznia i nauczyciela, Ecorys Polska Sp. z o.o., Warszawa 2011.

Bańka A., Zawodoznawstwo, doradztwo zawodowe, pośrednictwo pracy: psychologiczne metody i strategie pomocy bezrobotnym, PRINT-B, Poznań 1995.

Cybal-Michalska A., Młodzież akademicka a kariera zawodowa, Oficyna Wydawnicza Impuls, Kraków 2013.

Cybal-Michalska A., Dylematy tożsamościowe młodzieży w sytuacji zmiany kulturowej, [w:] Młodzież wobec niegościnnej przyszłości, red. R. Leppert, Z. Melosik, B. Wojtasik, DSWE, Wrocław 2005.

Denek K., Wartości edukacji zawodowej, Pedagogika Pracy, 1994, 23.

Griffin R.W., Podstawy zarzadzania organizacjami, Wydawnictwo Naukowe PWN, Warszawa 2007.

${ }^{22}$ A. Bańka, Zawodoznawstwo, doradztwo zawodowe, pośrednictwo pracy, s. 24.

${ }^{23}$ B. Wojtasik, Rozterki i niepokoje polskiego doradcy w realiach ponowoczesnego świata, [w:] Pedagogika pracy. Doradztwo zawodowe, red. H. Bednarczyk, J. Figurski, M. Żurek, Warszawa - Radom 2004, s. 42.

${ }^{24}$ A. Kargulowa, Doradca we wspótczesnym (nie)tadzie społecznym, [w:] Doradca - profesja, pasja, powotanie, red. B. Wojtasik, A. Kargulowa, Warszawa 2003, s. 39. 
Kargulowa A., Doradca we wspótczesnym (nie)ładzie społecznym, [w:] Doradca - profesja, pasja, powołanie, red. B. Wojtasik, A. Kargulowa, Stowarzyszenie Doradców Szkolnych i Zawodowych Rzeczpospolitej Polskiej, Warszawa 2003.

Łukasiewicz A., Sołtysińska G., Szkolny doradca zawodowy, Krajowy Ośrodek Wspierania Edukacji Zawodowej i Ustawicznej, Warszawa 2003.

Nowacki T.W., Jeruszka U., Podstawy dydaktyki pracy, Wyższa Szkoła Pedagogiczna Towarzystwa Wiedzy Powszechnej w Warszawie, Warszawa 2004.

Rosalska M., Warsztat diagnostyczny doradcy zawodowego, Krajowy Ośrodek Wspierania Edukacji Zawodowej i Ustawicznej, Warszawa 2012.

Sultana R., Strategie ustug poradnictwa zawodowego w społeczeństwie wiedzy - europejskie tren$d y$, dziatania i wyzwania, Raport CEDEFOP, Biuro Oficjalnych Publikacji Unii Europejskiej, Luksemburg 2004.

Szłapińska J., Podnoszenie wartości kapitału edukacyjnego pracowników w systemie kształcenia ustawicznego, Wydawnictwo Naukowe UAM, Poznań 2009.

Wierzejska J., Nowe obszary i problemy badawcze pedagogiki pracy, Wydawnictwo UMCS, Wydział Pedagogiki i Psychologii, Lublin 2017.

Wojtasik B., Rozterki i niepokoje polskiego doradcy w realiach ponowoczesnego świata, [w:] Pedagogika pracy. Doradztwo zawodowe, red. H. Bednarczyk, J. Figurski, M. Żurek, WSP ZNP, Warszawa, ITeE, Radom 2004.

\section{Netografia}

Belczyk K., Sedlak \& Sedlak, Praca - wartość i znaczenie na przestrzeni lat, [on-line] [dostęp: 05 styczeń 2016], dostępny w Internecie: http://www.rynekpracy.pl/artykul.php/ typ.1/kategoria_glowna.322/wpis.184.

Job shadowing [w:] Stownik HR, [on-line] [dostęp: 2 marzec 2016], dostępny w Internecie: http://www.jobfitter.pl/slownik-hr/job-shadowing.

Projekty ORE realizowane w latach 2016-2018 w ramach PO WER dotyczące kształcenia zawodowego, Doradztwo zawodowe - perspektywy i praktyczne rozwiazania, Wrocław 2017, http://dodn.dolnyslask.pl/images/p.\%20B.\%20Mayer-Gawron.pdf. [dostęp: 01.02.2018]. 